\title{
Miranda
}

Revue pluridisciplinaire du monde anglophone /

Multidisciplinary peer-reviewed journal on the English-

speaking world

$6 \mid 2012$

Marking the Land in North America

\section{Imprints in Space and Time}

\section{Nathalie Dessens and Wendy Harding}

\section{OpenEdition}

\section{Journals}

Electronic version

URL: http://journals.openedition.org/miranda/2818

DOI: $10.4000 /$ miranda.2818

ISSN: 2108-6559

\section{Publisher}

Université Toulouse - Jean Jaurès

\section{Electronic reference}

Nathalie Dessens and Wendy Harding, "Imprints in Space and Time", Miranda [Online], 6 | 2012, Online since 28 June 2012, connection on 16 February 2021. URL: http://journals.openedition.org/miranda/ 2818 ; DOI: https://doi.org/10.4000/miranda.2818

\section{This text was automatically generated on 16 February 2021.}

\section{$\Theta \Theta \Theta \Theta$}

Miranda is licensed under a Creative Commons Attribution-NonCommercial-NoDerivatives 4.0 International License. 


\title{
Imprints in Space and Time
}

\author{
Nathalie Dessens and Wendy Harding
}

1 One of the recurrent myths governing the complex history of the occupation of North America is that the territory was a virgin land, a blank page available for cultural inscription. This assumption appears in writings as diverse of those of the seventeenthand eighteenth-century Puritans and the Sierra Club of today. It resonates in Charles Olson's oft-quoted statement: "I take SPACE to be the central fact to man born in America. I spell it large because it comes large here. Large and without mercy" (11). The tendency to represent America as a vast territory always open for discovery and exploration denies the continuities and disruptions that have characterized the story of human occupation. It denies the ways in which "time and space are implicated in each other" (Massey 18). Through the actions of marking and being marked, time and space come together in infinitely varied configurations. The land bears the traces of the lives that come into contact with it, just as those lives are shaped by interactions with the land. The theme of "Marking the land" thus encompasses the imprints that humans have left on the land and those that the land has left on them. The inscriptions considered here are material, monumental, and literary.

2 While they focus on particular cultural and historical moments, the essays collected here suggest the rich and problematic engagement that Americans have experienced with the national territory. Although refuted by Lionel Larré in the first article, the myth that the continent was originally unmarked persists. In various ways, EuroAmerican inhabitants have continued to inscribe the land with the marks of their presence, tracing boundaries (Nègre), remodeling landscapes (Lemaire and Sisto; Rigaud), and creating memorials to human activity (Bardet). At the same time, the inhabitants of North America have left literary traces of their engagement with the land, marking the page in various ways, but especially in a particularly American mode that interweaves reflections on inner and outer space. Lionel Larré terms this autobiogeo-graphy in his essay on the work of John Joseph Mathews and other Native American writers. In a humorous vein Mark Twain, in Roughing It (Louis-Dimitrov), writes of the fantasy and the lure of marking virgin space. Finally, Michaela Kahn adds 
her own voice to this American auto-biogeo-graphical chorus in writing about her native Los Angeles.

The first of the essays in Marking the Land in North America, Lionel Larré's, "II have made a footprint, through it the blades push upward': Marking the Land while Talking to the Moon," reconsiders, in the wake of Shepard Krech, the concept of Native Americans as an "ecological" people who inhabited the continent without leaving any durable traces. Larré's exploration of John Joseph Mathews's 1945 autobiographical text, Talking to the Moon, alongside other Native American writers such as N. Scott Momaday, Louis Owens, and Standing Bear, reveals instead their reciprocal relation with the land: they mark the land as well as being marked by it. The writers Larré considers retranscribe the imprint made by their surroundings, showing through their personal experience, how "Nature makes the man to fit his surroundings" (Luther Standing Bear, quoted by Larré). This reciprocal action results in texts that Larré describes not as "nature writing" or "environmental literature" (the conventional terms) but as "auto-biogeography," alluding to Michel Serres' term Biogée. Even though Mathews protests that writing is inadequate to convey a relationship that is above all physical connection, his book successfully relates his quest to reconnect with his tribe (the Osage) and his native land (the Blackjacks of northern Oklahoma).

The remaining essays in the collection consider the more problematic interactions with the land initiated by the European colonists and their descendants. One of America's many founding myths is that the settlers found an empty land without any history, a blank surface waiting for their inscription. It was probably easy for the first colonists to imagine America as such. Indeed, Julien Nègre, in "A Straight Line through the Wilderness: Geometry and Geography in William Byrd's Histories of the Dividing line Betwixt Virginia and North Carolina (1728 sqq)," recounts the history of the survey, in 1728, of a straight line dividing the colonies of Virginia and North Carolina, as told by the surveyor William Byrd II in two journals-an official manuscript acquired by the American Philosophical Association in Philadelphia in the late eighteen ${ }^{\text {th }}$ century and a "secret" one, found in the Byrd family's archive by Thomas Jefferson himself in 1817, transmitted to the American Philosophical Association, and containing more personal details on the surveying expedition. What Nègre's article shows is the way in which the surveying experience influenced Byrd's perception of the land but also how the line became an instrument of control and appropriation of the land, epitomizing the marks made upon the American land by early European colonization.

5 By the time Mark Twain traveled west of the Mississippi in the mid-nineteen ${ }^{\text {th }}$ century, the territory had already been marked by Euro-American settlement and, more to the point, inscribed in multiple forms of discourse that shaped a national myth. Delphine Louis-Dimitrov looks at Twain's response to the legendary West in her essay, "The Unreliable Traces of the West: Mark Twain's Appropriation of a Symbolical Landscape in Roughing It." Twain takes up the conventional comparison between the American grasslands and an unmarked and limitless ocean; at the same time though, he describes the traces left by settlement. Louis-Dimitrov interprets Twain's representation of the stereotyped and ineffectual markings left by the movement westward as a critique of Americans' displacement. Twain's westward journey is ambivalently prospective and retrospective, for the traveler discovers the relics of the failed dreams of would-be settlers. Though the American prairies are places of loss and oblivion, they are not sites of tragedy for the author. Instead his parodies and pastiches humorously debunk 
American legends and demystify the American sublime. With this palimpsestic text, Twain adds his own highly distinctive mark to Western legends.

The Euro-American mission to bring the North American continent under the sway of a civilizing force sometimes results in ecological disasters, as Janine Lemaire and Bénédicte Sisto show in their article, "The Everglades Ecosystem: Under Protection or Under Threat?" Like the American West, Florida has been the site of ambitious projects to remold the land for human habitation-to the detriment of other forms of life already implanted there. Lemaire and Sisto recount the history of the Florida Everglades, showing how human intervention, taking the form of various drainage projects designed to clear swampland for agriculture and settlement, has wreaked havoc in the ecosystem. The fight to remedy the situation inevitably encounters the resistance of the many groups with financial stakes in the drained land. Since, due to the need to reconcile various interest groups, the restoration of the ecosystem can only be partial, Lemaire and Sisto are pessimistic about the possibility of returning the land to health.

7 If the settlement of Europeans in America left clear marks on the land in the colonial era and in the early American republic, other kinds of marks were left on the landscape in later periods. Among those marks, some relate to the memorializing of American experience. Pascal Bardet, in his article entitled "Demarcating Territory: Historical Markers in the United States," examines the meaning (or sometimes the absence thereof) of the historical markers that started being erected in the 1930s. He shows how those markers testify to a new display of territorial appropriation. The mechanism of this new appropriation is sometimes not very different from those involved in the surveys conducted in earlier eras, such as the process narrated by William Byrd II.

A very different way of marking the American territory is pursued in the Land Art that developed in the 1960s with the rise of environmentalism and the reconsideration of the community's relationship to the land. As Antonia Rigaud shows in "Disorienting Geographies: Land Art and the American Myth of Discovery," the Land Art movement is both innovative and retrospective. In inaugurating new forms of aesthetic discourse, artists such as Walter De Maria, Michael Heizer, and Robert Smithson also revisit the founding myths of the nation, harking back to the Puritan view of the land "as both a text and a place of salvation (or perdition)." Land Artists perpetuate the myth of the land as a blank page ready for inscription, or, in a more ecological vein, they engage in what Rigaud calls a "counter narrative" to Americans' industrial and technological devastation of the environment. Through its ritualistic restructuring of space, Land Art asks us to reenact the recurrent American narrative of discovery and to question it at the same time.

9 The final essay in this collection, Michaela Kahn's "Los Angeles: Coyotes, Smoke \& Mirrors," departs from the usual academic format and introduces Miranda readers to her creative non-fiction. While Kahn's meditation on her native Los Angeles draws widely on scholarly studies and archival sources, it weaves the historical facts concerning the area's settlement together with author's personal memories and dreams, so that readers understand the traumatic effects of environmental exploitation. Kahn's essay reveals how the land of her birth has marked her, shaping her thoughts and longings. Of course, Los Angeles is diametrically opposed to John Joseph Mathews' native Blackjacks region, as described in Lionel Larré's opening essay; the city oppresses rather than nurtures. In witnessing the transformation of Los 
Angeles from a rural to an urban space, achieved by laying millions of tons of concrete, Kahn feels suffocated like the land itself. Her writerly response to the city's denaturalization takes the form of an elegy to a lost home. Her essay questions the extent to which humans can reshape their environment to meet their needs before they reach the point where it no longer sustains them, either physically or spiritually. In her consideration of her native city, Kahn illustrates how inhabitation is reciprocal; it means both marking and being marked by one's surroundings.

Ranging widely through the cultural geography and history of North America, the essays in this collection suggest the variety of ways in which the land marks its inhabitants and is marked in turn. They show how human culture cannot be considered apart from the environment; the two are mutually engaged in ongoing processes of reform(ul)ation. In exploring a range of interactions, from the catastrophic to the harmonious, these essays remind us of our responsibility toward the places we inhabit, thereby fulfilling one of the primary goals of ecocriticism.

\section{BIBLIOGRAPHY}

Krech, Shepard III. The Ecological Indian: Myth and History. New York: Norton, 1999.

Massey, Doreen. For Space. London: Sage, 2005.

Olson, Charles. Call Me Ishmael. San Francisco: City Lights Books, 1947.

\section{AUTHORS}

\section{NATHALIE DESSENS}

Professeur

Université Toulouse 2 - Le Mirail

dessens@univ-tlse2.fr

WENDY HARDING

Professeur

Université Toulouse 2 - Le Mirail

harding@univ-tlse2.fr 